\title{
Waardenburg Syndrome
}

National Cancer Institute

\section{Source}

National Cancer Institute. Waardenburg Syndrome. NCI Thesaurus. Code C85222.

A rare, autosomal dominant inherited syndrome caused by mutations in the PAX3, MITF, and SNAI2 genes. Signs and symptoms include hearing loss, dystopia canthorum (widely spaced inner corners of the eyes), and changes in the color of the skin, hair, and eyes. 